\title{
Monitoring on the Presence of Ascorbic Acid in Not Prepacked Fresh Meat Preparations by a Validated HPLC Method
}

\author{
Marco Iammarino (Corresponding author) \\ Struttura Complessa "Chimica", Istituto Zooprofilattico Sperimentale della Puglia e della Basilicata \\ Foggia 71121, Italy \\ Tel: 39-088-178-6381Ｅ-mail: marco.iammarino@tin.it \\ Aurelia Di Taranto \\ Struttura Complessa "Chimica", Istituto Zooprofilattico Sperimentale della Puglia e della Basilicata \\ Foggia 71121, Italy \\ Tel: 39-088-178-6325 E-mail: a.ditaranto@izsfg.it
}

Received: January 6, $2012 \quad$ Accepted: January 19, $2012 \quad$ Published: May 1, 2012

doi:10.5539/jfr.v1n2p22 URL: http://dx.doi.org/10.5539/jfr.v1n2p22

\begin{abstract}
Ascorbic acid is a commonly-used food additive permitted in prepacked fresh meat preparations. Consequently, the addition of this antioxidant is subject to a specific packaging authorization. In this survey 180 samples of not prepacked fresh meat preparations have been analyzed in order to evaluate the diffusion of not authorized ascorbic acid additions. The ascorbic acid has been determined by a high performance liquid chromatography with diode array detection method, validated according to the European Legislation. Quantifiable concentrations of ascorbic acid ( $>\mathrm{LOQ}=20.1 \mathrm{mg} \cdot \mathrm{kg}^{-1}$ ) were registered in 33 samples confirming a wide diffusion of not authorized additions. Moreover, low concentrations not attributable to a additives additions were detected in 14 samples. Ascorbic acid sources (tomato) were declared on the label of these samples. Considering that the addition of this food additive is generally considered safe, these low concentrations registered may be useful for the determination of an allowable limit for the ascorbic acid in not prepacked fresh meat preparations.
\end{abstract}

Keywords: Ascorbic acid, Food additives, Meat preparations, Liquid chromatography, Validation

\section{Introduction}

The L-ascorbic acid and its salts (ascorbates) are commonly-used food additives permitted by the actual Normative in fresh meat preparations (hamburger, fresh sausages and minced meats) (Table 1). The ascorbic acid is a food antioxidant; the actual European Normative (European Commission, 2011) does not define legal limits for its employment, it makes reference to an ambiguous "quantum satis".

This food additive is used in fresh meat preparations because it may exercise the following activities: meat colour development, inhibition of nitrosamines formation and prevention of oxidation and of colour fading also during product storage.

The characteristic cured meats colour is obtained by reduction of nitrosometamyoglobin to nitrosomyoglobin. The oxidation of ascorbic acid to dehydroascorbic acid that occurs when this additive is added to cured meats may accelerate this reduction (Watts \& Lehmann, 1952; Izumi, 1992; Nam \& Ahn, 2003). In addition, the ascorbic acid antioxidant action prevents the myoglobin oxidation to metamyoglobin which has a brown colour (Hughes, 2003).

The ascorbic acid may prevent the nitrosamines formation in meats through the reduction of nitrate to nitrogen oxide that does not react with secondary amines to form nitrosamines (Kalus \& Filby, 1980; Hotchkiss \& Cassens, 1987; Tannenbaum et al., 1991).

Finally, the lipids oxidation may be retarded because the ascorbic acid addition and the consequent oxidation of this additive reduces the oxygen available for lipids breakdown (Roig et al., 1993; Hillstrom et al., 2003). 
Is important to underline that this additive is permitted only in prepacked preparations of fresh minced meat. Consequently, a specific duty to obtain a food packaging authorization, released by the local health authority, subsists for the producer.

However, this duty is not respected in several cases. This is especially due to a law misinterpreting. In fact, the producers do not know the duty to obtain a packaging authorization and then they add this additive in prepacked products because ascorbic acid is permitted in minced meat preparations by the actual Normative (Paturzo \& Bizzozero, 2001; Iammarino et al., 2010).

In this work 180 samples of not prepacked fresh meat preparations (hamburger, fresh sausages and minced meats) were analyzed in order to evaluate the extent to which not authorized ascorbic acid addition is diffused.

The ascorbic acid has been determined by a high performance liquid chromatography with diode array detection method, validated according to the European Legislation.

In many samples low concentrations of ascorbic acid, not attributable to an additive addition, were detected. These concentrations were elaborated in order to evaluate a value that may be suggested as maximum admissible limit for ascorbic acid in not prepacked fresh meat preparations.

\section{Materials and Methods}

The investigation was performed on 180 samples of not prepacked fresh meats preparations (hamburger, fresh sausages and minced meats) composed of pork, cow, horse, chicken and mixed meats.

The samples were collected on several markets located in Foggia (Italy) during the period June 2010 November 2011. Two replicates of each sample were analysed and the ascorbic acid contents were evaluated as mean of two measurements.

\subsection{Chemicals and working standard solutions}

L-Ascorbic acid ( $\geq 99.0 \%)$ and sodium acetate anhydrous were supplied by Sigma-Aldrich (Stenheim, Germany). Phosphoric acid (85.0\%), acetic acid glacial and acetonitrile of HPLC grade were purchased from J.T. Baker (Deventer, Netherlands). Potassium phosphate monobasic $(\geq 98.0 \%)$ and potassium phosphate bibasic $(\geq 98.0 \%)$ were supplied by Carlo Erba Reagenti (Milan, Italy). All solutions were prepared in ultrapure water with a specific resistance of 18.2 M $\Omega$-cm, supplied by a Milli-Q RG unit, Millipore (Bedford, MA, USA).

\subsection{Sample preparation}

A 4-g portion of sample (different types of fresh meat preparation), homogenized by blade homogenizer, was mixed with $40 \mathrm{~mL}$ of phosphate buffer $10^{-2} \mathrm{M} \mathrm{pH} 3.5$, obtained dissolving $1.36 \mathrm{~g}$ of potassium phosphate monobasic and $1.74 \mathrm{~g}$ of potassium phosphate bibasic in $1000 \mathrm{~mL}$ of ultrapure water and then correcting the $\mathrm{pH}$ value to 3.5 by addition of phosphoric acid. The mixture was vortexed for one minute. After centrifugation for 5 $\min$ at $250 \mathrm{xg}$ at room temperature, the supernatant was filtered through Whatman No. 40 filters (Whatman, Springfield Mill, UK) and then about $1.5 \mathrm{~mL}$ were filtered through Anotop $10 \mathrm{LC}, 0.2 \mu \mathrm{m}, 10 \mathrm{~mm}$ filters (Whatman, Springfield Mill, UK) directly in vial prior to chromatographic analysis.

\subsection{Apparatus and method}

The chromatographic method for the determination of ascorbic acid in meat products was optimized starting from a chromatographic separation proposed by Phenomenex (Torrance, CA) (Phenomenex Inc., 2011) that employs the Reversed Phase Liquid Chromatography coupled with UV-Diode Array Detection (UV-DAD) (Iammarino \& Di Taranto, 2011). All the chromatographic separations were performed on a HPLC system, Waters $^{\text {TM }} 2690$ Separations Module (Milford, MA) equipped with a Waters ${ }^{\text {TM }} 996$ PDA Detector (Milford, MA), a micro vacuum degasser, an autosampler and a column compartment. The chromatographic column was a Luna C18 column $(250 \times 4.6 \mathrm{~mm}$ i.d., particle size $5 \mu \mathrm{m}$. Phenomenex, Torrance, CA $)$ equipped with a HILIC Security Guard Cartridge $\left(4 \times 3.0 \mathrm{~mm}\right.$. Phenomenex, Torrance, CA), operating at a flow-rate of $1.5 \mathrm{~mL} \mathrm{~min}^{-1}$ following the gradient elution of acetonitrile, water and acetate buffer $100 \mathrm{mM}, \mathrm{pH} 5.8$ described in table 2 .

Acetate buffer was obtained dissolving $7.708 \mathrm{~g}$ of sodium acetate in $1000 \mathrm{~mL}$ of ultrapure water and then correcting the $\mathrm{pH}$ value to 5.8 by addition of glacial acetic acid.

The absorbance signal was detected at $260 \mathrm{~nm}$. Setting the acquisition wavelength range from 200 to $500 \mathrm{~nm}$, the diode array detector allows to obtain the ascorbic acid absorbance spectrum. It is possible to compare the spectrum of sample with the spectrum of a standard solution and increase the method selectivity though this comparison. 


\subsection{Validation procedures}

The analytical method optimized for the ascorbic acid determination in meat products was validated by an in-house validation model, following the Thompson harmonized validation guidelines (Thompson et al, 2002) which describes the analytical parameters to appraise to assure the method reliability in agreement with Regulation 882/2004/EC (European Commission, 2004) and Decision 657/2002/EC (European Commission, 2002).

The parameters evaluated were linearity, specificity, detection and quantification limits (LOD and LOQ), accuracy, ruggedness and measurement uncertainty.

The method linearity was verified by the injection, on three different days, of three series of standard solutions at ascorbic acid concentrations of $12.5,25,50,100$ and $200 \mathrm{mg} \cdot \mathrm{L}^{-1}$. The linearity was verified for each calibration curve and for the mean curve verifying the determination coefficient values $\left(\mathrm{r}^{2}\right)$, higher than 0.990 , where standard deviations of slope and intercept are estimated at the $95 \%$ confidance level (Table 3). A chromatogram of an ascorbic acid standard solution at a concentration of $50 \mathrm{mg} \cdot \mathrm{L}^{-1}$ is reported in figure 1 with related absorbance spectrum.

The limit of detection (LOD) and quantification (LOQ) were elaborated according to the following equations: $\mathrm{LOD}=3.3 \mathrm{~s}_{\mathrm{a}} / \mathrm{b}$ and $\mathrm{LOQ}=10 \mathrm{~s}_{\mathrm{a}} / \mathrm{b}$ (Miller \& Miller, 1993), where $\mathrm{s}_{\mathrm{a}}$ is the standard deviation of the intercept and $\mathrm{b}$ is the slope of the linear regression. LOD and LOQ values of $6.6 \mathrm{mg} \cdot \mathrm{kg}^{-1}$ and $20.1 \mathrm{mg} \cdot \mathrm{kg}^{-1}$, respectively, were obtained (Table 3).

The method specificity was demonstrated by analysing 20 fresh meat samples $(5$ cow, 5 , pork, 5 horse and 5 chicken) and verifying the absence of interfering peaks in the retention time-window of interest $( \pm 2.5 \%$ of ascorbic acid retention time). In Figure 2 a chromatogram of a blank fresh meat sample is shown; the ascorbic acid is well separated from endogenous compounds under the optimized gradient elution, and the chromatogram is interference-free in the time-window of elution of the analyte.

Repeatability and recovery (accuracy) were evaluated by performing tests on three sets of blank cow fresh meat samples (six replicates each) fortified with ascorbic acid at concentrations of 50,500 and $1000 \mathrm{mg} \mathrm{kg}^{-1}$. The analyses were executed on different days by the same instrument but different operators (Intermediate Precision). The precision (expressed as $\mathrm{CV} \%$ ) and the recovery percentages obtained are reported in Table 4. By comparison with maximum standard deviations admitted by Horwitz equation, as reported in Decision (EC) No. $657 / 2002$, the method precision was demonstrated. The recovery percentages, in the range $80-110 \%$ (reference range indicated in Decision (EC) No. 657/2002 for mass fraction $\geq 10 \mu \mathrm{g} \mathrm{kg}^{-1}$ ) demonstrated the method trueness.

Method ruggedness under major changes conditions was evaluated by using the Youden factorial experimental design (Youden \& Steiner, 1975). The seven factors chosen as variables for Youden test were the matrix and six fictitious factors. Consequently, the Youden experimental design requires twelve independent experiments: four with validation matrix (cow fresh meat) and four with each testing matrices. Different types of fresh meat samples: 4 pork, 4 horse and 4 chicken, fortified with $500 \mathrm{mg} \cdot \mathrm{kg}^{-1}$ of ascorbic acid were analysed. The analyses of alternatives matrices (pork, horse and chicken fresh meats) gave a calculated standard deviation of difference $\left(\mathrm{S}_{\mathrm{Di}}\right)$ lower than the estimated method precision $\left(\mathrm{S}_{\mathrm{Di}}=8.0\right)$, evaluated as twice the repeatability standard deviation of cow fresh meat samples at a fortification level of $500 \mathrm{mg} \cdot \mathrm{kg}^{-1}$. These results confirmed that the matrix variation has no effect on the analytical performances and consequently the method is also applicable to pork, horse and chicken fresh meat samples.

The estimation of the measurement uncertainty is compulsory for laboratories accredited ISO 17025 (International Organization for Standardization, 2000). Several approaches have been proposed for the determination of this parameter (EURACHEM/CITAC, 2000), in this work the bottom-up method using the data obtained from each step of the analytical procedure was used (Hund et al, 2001). The measurement uncertainty was calculated on the basis of the uncertainties propagation law, by the equation:

$$
\bar{u}=\sqrt{ }(\bar{u}(C))^{2}+\left(\bar{u}\left(V_{f}\right)\right)^{2}+(\bar{u}(w))^{2}
$$

Where $\bar{u}$ indicates the relative uncertainty, $C$ is the analyte concentration in matrix, $V_{\mathrm{f}}$ is the final extract volume and $\mathrm{w}$ is the sample weight. The determination of $\overline{\mathrm{u}}(\mathrm{C})$ was performed considering four uncertainty sources: (a) standards preparation; (b) method repeatability; (c) method recovery; (d) calibration curve. A relative expanded measurement uncertainty of $5.6 \%$ was obtained by using a coverage factor $\mathrm{k}$ of 2 , corresponding approximately to a $95 \%$ confidence level. This parameter confirmed the method reliability and the laboratory technical competence in the quantitative determination of the ascorbic acid in meat products. 


\section{Results and Discussion}

The results of the analyses performed on 180 samples of cow, pork, horse, chicken and mixed fresh meat preparations (hamburger, fresh sausages and minced meats), collected in local markets of Foggia (Italy) are reported in table 5. The samples resulted "positive" for ascorbic acid (> LOQ $\left.=20.1 \mathrm{mg} \cdot \mathrm{kg}^{-1}\right)$ (33 samples, equal to $18.3 \%$ ) were classified into two categories in relation to the measured concentrations.

In the first category, of "not-compliant" (19 samples, equal to 10.6\%), the samples with ascorbic acid concentrations higher than $160.0 \mathrm{mg} \mathrm{kg}^{-1}$ were inserted. These high ascorbic acid concentrations are surely to attribute to not allowed additive additions.

In the range $41.2-160.0 \mathrm{mg} \mathrm{kg}^{-1}$ there were no samples with quantifiable concentrations of ascorbic acid, so it was considerate a second category, of "compliant" (14 samples, equal to 7.8\%), including the samples with ascorbic acid concentrations lower than $41.2 \mathrm{mg} \cdot \mathrm{kg}^{-1}$. It is important to underline the presence of tomato (fresh, sauce or tinned peeled), reported on the products labels of these samples,.

In Graphic 1 the subdivision into negative, "compliant", and "not-compliant" samples is shown.

A comparison between two chromatograms related of these two categories of positive samples is reported in Figure 2 .

The fraudulent addition of ascorbic acid in the samples with low concentrations of ascorbic acid ("compliant samples") seems not likely. In fact, the ascorbic acid cannot exercise a useful antioxidant activity at these levels. Reading the products ingredients reported on the labels, it seems more appropriate to attribute such ascorbic acid residues to the presence of tomato (fresh, sauce or tinned peeled).

Considering that the ascorbic acid addition to foodstuffs is generally considered as safe (FDA, 1979) it is possible to suggest a maximum admissible level in not prepacked fresh meat preparations, if ascorbic acid sources (such as tomato) are indicated on the product label.

In order to simplify the identification of this cutoff value, the distribution of the ascorbic acid concentrations registered is described in Figure 3, (the samples with ascorbic acid concentrations higher then $400 \mathrm{mg} \mathrm{kg}^{-1} \mathrm{are}^{-}$ not included). It is possible to verify that there are no "compliant" samples that exceed $50 \mathrm{mg} \mathrm{kg}^{-1}$ of ascorbic acid.

Taking into account the distribution of the observed ascorbic acid concentrations, considering the measurement uncertainty of the method $(5.6 \%)$ and an appropriate tolerance, it is possible to suggest a maximum allowable limit of $50.0 \mathrm{mg} \mathrm{kg}^{-1}$ in not prepacked fresh meat preparations (in the presence of ascorbic acid sources). Below this value the sample should be considered as "compliant".

Numerous cases of not allowed ascorbic acid additions were verified during this survey.

Through this monitoring it was possible to verify that these irregularities are probably not attributable to a real necessity for the producer, but to a lacking disclosure of the legislation.

In fact, the most part of producers were not informed on the limitations related to the ascorbic acid use, and they proceed with this additive addition because it is permitted in minced meat preparations by the actual Normative.

Considering the high percentage of positive samples registered there is the necessity to more disclose this duty law.

\section{Conclusions}

From a survey of 180 not prepacked fresh meat preparations samples, ascorbic acid concentrations higher than the method limit of quantification ( $\mathrm{LOQ}=20.1 \mathrm{mg} \mathrm{kg}^{-1}$ ) were registered in 33 samples. In 19 samples ascorbic acid concentrations from $160.0 \mathrm{mg} \mathrm{kg}^{-1}$ until to $4170.0 \mathrm{mg} \mathrm{kg}^{-1}$, surely to attribute to not allowed additive additions, were registered. In 14 samples such concentrations were in the range $21.9-41.2 \mathrm{mg} \mathrm{kg}^{-1}$. These low concentrations are probably to attribute to the presence of ascorbic acid sources (such as tomato) in the product.

Considering the high percentage of positive samples registered, there is the necessity to more disclose the duty law that foresees the obtainment of a packaging authorization for the producer that wants to add ascorbic acid in prepacked products.

In addition, taking into account the distribution and the percentages of ascorbic acid registered at low concentration, it is possible to suggest a cut-off value of $50.0 \mathrm{mg} \mathrm{kg}^{-1}$. This value may be useful for a future estimation of a maximum allowable limit for the ascorbic acid in not prepacked fresh meat preparations, if ascorbic acid sources are present in the product formulation. 


\section{Acknowledgments}

Ministero della Salute (Rome, Italy) is gratefully acknowledged for providing the financial support.

\section{References}

EURACHEM/CITAC. (2000). GUIDE CG 4: Quantifying Uncertainty in Analytical Measurement. Ellison, S. L. R., Rosslein, M., Williams, A. (Eds). (2nd ed.), Teddington (UK).

European Commission. (2002). Decision (EC) No. 657/2002. 12 August 2002. Official Journal of the European Union, 221, 8-36.

European Commission. (2004). Regulation (EC) No. 882/2004. 29 April 2004. Official Journal of the European Union, 165, 1-141.

European Commission. (2011). Commission Regulation (EU) No 1129/2011 of 11 November 2011 amending Annex II to Regulation (EC) No 1333/2008 of the European Parliament and of the Council by establishing a Union list of food additives. Journal of the European Union, 295, 98-99.

Food and Drug Administration. (1979). Database of Select Committee on GRAS Substances (SCOGS) Reviews, L-ascorbic acid, Report No. 59, ID Code 50-81-7.

Hillstrom, R. J., Yacapin-Ammons, A. K., \& Lynch, S. M. (2003). Vitamin C inhibits lipid oxidation in human HDL. J. Nutr., 133(10), 3047-51.

Hotchkiss, J. H., \& Cassens, R. G. (1987). Nitrate, nitrite and nitroso compounds in foods. Food Technol, 41(4), 127-134.

Hughes, H. (2003). Best Food Writing. New York: Marlowe \& Company.

Hund, E., Massart, D. L., \& Smeyers-Verbeke, J. (2001). Operational definitions of uncertainty. Trends Analytcal Chemistry, 20(8), 394-406. http://dx.doi.org/10.1016/S0165-9936(01)00089-9

Iammarino, M., \& Di Taranto A. (2011). Preparazioni carni fresche: HPLC per la determinazione di sostanze antiossidanti non ammesse. Laboratorio 2000, 44-50.

Iammarino, M., Di Taranto, A., \& Muscarella, M. (2011). Investigation on the natural presence of substances with preservative effects in minced meat preparations. Ingredienti Alimentari, 15-23.

International Organization for Standardization. (2000). General requirements for the competence of testing and calibration laboratories.

Izumi, K. (1992). Reaction of nitrite with ascorbic acid or ascorbic acid-2-derivatives. J. Food. Sci., 57, 1066. http://dx.doi.org/10.1111/j.1365-2621.1992.tb11264.x

Kalus, W. H., \& Filby, W. G. (1980). Inhibition of nitrosamine formation by ascorbic acid: participation of free radicals in its anaerobic reaction with nitrite. Cellular and Molecular Life Sciences., 36(2), 147-149. http://dx.doi.org/10.1007/BF01953698

Miller, E. J. C. \& Miller, J. N. (1993). Statistics for Analytical Chemistry (3rd ed.), New York, NY, USA: Ellis Horwood PTR Prentice Hall, p.115.

Nam, K. C., \& Ahn, D. U. (2003). Effects of ascorbic acid and antioxidants on the color of irradiated ground beef. Journal of food science, 68(5), 1686-1690. http://dx.doi.org/10.1111/j.1365-2621.2003.tb12314.x

Paturzo, F., \& Bizzozero, N. (2001). Risultati di un'indagine sul contenuto di additive in campioni commerciali di carne trita. Ingegneria Alimentare, 3, 15-16.

Phenomenex, Inc. (2011). Chromatography Product Guide 11/12. Vitamin Mix on Luna HILIC, p. 207.

Roig M. G., Rivera, Z. S., \& Kennedy J. F. (1993). L-ascorbic acid: An overview. International Journal of Food Sciences and Nutrition, 44(1), 59-72. http://dx.doi.org/10.3109/09637489309017424.

Tannenbaum, S. R., Wishnok, J. S., \& Leaf, C. D. (1991). Inhibition of nitrosamine formation by ascorbic acid. Am. J. Clin. Nutr, 53(1 Suppl). 247S-250S. http://dx.doi.org/10.1111/j.1749-6632.1987.tb23774.x

Thompson, M., Ellison, S. R. L., \& Wood, R. (2002). Harmonized guidelines for single laboratory validation of methods of analysis. Pure Appl. Chem, 74(5), pp. 835-855. http://dx.doi.org/10.1351/pac200274050835

Watts, B. M., \& Lehmann, B. T. (1953).The effect of ascorbic acid on the oxidation of hemoglobin and the formation of nitric oxide hemoglobin. Journal of food science, 17, 100-108. http://dx.doi.org/10.1111/j.1365-2621.1952.tb16744.x 
Youden, W. J., \& Steiner, E. H. (1975). Statistical Manual of the AOAC - Association of the Official Analytical Chemists. AOAC-I, Washington, DC, p. 35.

Table 1. Food additives permitted in prepacked preparations of fresh minced meat

\begin{tabular}{ccc}
\hline E-number & Name & Maximum level \\
\hline E 261 & Potassium acetate & quantum satis \\
E 262 & Sodium acetates & quantum satis \\
E 300 & Ascorbic acid & quantum satis \\
E 301 & Sodium ascorbate & quantum satis \\
E 302 & Calcium ascorbate & quantum satis \\
E 325 & Sodium lactate & quantum satis \\
E 326 & Potassium lactate & quantum satis \\
E 330 & Citric acid & quantum satis \\
E 331 & Sodium citrate & quantum satis \\
E 332 & Potassium citrate & quantum satis \\
E 333 & Calcium citrate & quantum satis \\
\hline
\end{tabular}

Table 2. Gradient elution settings

\begin{tabular}{cccc}
\hline Time (minutes) & \%A (Acetonitrile) & $\mathbf{\% B}$ (Water) & \%C (Acetate buffer) \\
\hline 0.0 & 90 & 5 & 5 \\
2.5 & 90 & 5 & 5 \\
7.5 & 50 & 45 & 5 \\
10.0 & 50 & 45 & 5 \\
11.0 & 90 & 5 & 5 \\
15.0 & 90 & 5 & 5 \\
\hline
\end{tabular}

Table 3. Calibration parameters and decision limits

\begin{tabular}{ccccc}
\hline \multicolumn{5}{c}{$y=a+b x^{a}$} \\
\hline $\mathrm{a} \pm \mathrm{SD}$ & $\mathrm{b} \pm \mathrm{SD}$ & $\mathrm{R}^{2 \mathrm{~b}}$ & $\mathrm{LOD}^{\mathrm{c}}$ & $\mathrm{LOQ}^{\mathrm{c}}$ \\
$(3.5 \pm 4.8) 10^{4}$ & $(92.0 \pm 0.9) 10^{3}$ & 0.9997 & 6.6 & 20.1
\end{tabular}

\footnotetext{
${ }^{\mathrm{b}}$ Determination coefficient.

${ }^{\mathrm{c}}$ Expressed as ascorbic acid in $\mathrm{mg} \cdot \mathrm{kg}^{-1}$ of sample.
}

${ }^{\mathrm{a}} \mathrm{y}$ is the peak area of ascorbic acid and $\mathrm{x}$ is the concentration in $\mathrm{mg} \cdot \mathrm{L}^{-1}$. 
Table 4. Precision and recovery of the validated method

\begin{tabular}{|c|c|c|c|c|c|}
\hline \multicolumn{6}{|c|}{ Ascorbic Acid } \\
\hline \multirow{2}{*}{\multicolumn{3}{|c|}{$\begin{array}{l}\text { CV\% } \\
(n=6)\end{array}$}} & \multirow{2}{*}{\multicolumn{3}{|c|}{$\begin{array}{l}\text { Recovery \% } \\
(n=6)\end{array}$}} \\
\hline & & & & & \\
\hline Fortification & Fortification & Fortification & Fortification & Fortification & Fortification \\
\hline level: & level: & level: & level: & level: & level: \\
\hline $50 \mathrm{mg} \cdot \mathrm{kg}^{-1}$ & $500 \mathrm{mg} \cdot \mathrm{kg}^{-1}$ & $1000 \mathrm{mg} \cdot \mathrm{kg}^{-1}$ & $50 \mathrm{mg} \cdot \mathrm{kg}^{-1}$ & $500 \mathrm{mg} \cdot \mathrm{kg}^{-1}$ & $1000 \mathrm{mg} \cdot \mathrm{kg}^{-1}$ \\
\hline 3.8 & 4.0 & 5.3 & 100.9 & 97.7 & 104.0 \\
\hline
\end{tabular}

Table 5. Results obtained by analysing 180 fresh meat preparations samples

\begin{tabular}{|c|c|c|c|c|}
\hline $\begin{array}{l}\text { Type of fresh meat } \\
\text { preparation }\end{array}$ & Meat origin & $\begin{array}{c}\text { Negative samples } \\
\left(<\mathrm{LOQ}=20.1 \mathrm{mg} \cdot \mathrm{kg}^{-1}\right)\end{array}$ & $\begin{array}{c}\text { "Not-compliant" samples } \\
\text { Concentration range }{ }^{a} \text { : } \\
{[160-4170]}\end{array}$ & $\begin{array}{c}\text { “Compliant" samples } \\
\text { Concentration range }^{a} \text { : } \\
{[21.9-41.2]} \\
\end{array}$ \\
\hline \multirow{4}{*}{$\begin{array}{l}\text { Hamburger } \\
\text { (59 samples) }\end{array}$} & Cow (16) & 12 & $\begin{array}{c}1 \\
190.0 \pm 10.6\end{array}$ & \begin{tabular}{c}
\multicolumn{3}{c}{3} \\
$22.6 \pm 1.3$ \\
$36.6 \pm 2.0$ \\
\end{tabular} \\
\hline & Pork (12) & 8 & $\begin{array}{c}2 \\
330.0 \pm 18.5 \\
223.0 \pm 12.5 \\
\end{array}$ & $25.6 \pm 1.4 \quad 2 \quad 29.6 \pm 1.7$ \\
\hline & Chicken (5) & 5 & 0 & 0 \\
\hline & Cow/Pork (26) & 19 & $\begin{array}{c}4 \\
1259.0 \pm 70.5 \\
4170.0 \pm 233.5 \\
1600.0 \pm 89.6 \\
200.0 \pm 11.2\end{array}$ & $\begin{array}{c}{ }^{3} 3 \\
36.9 \pm 1.8 \\
36.1\end{array}$ \\
\hline \multirow{6}{*}{$\begin{array}{l}\text { Fresh sausages } \\
\text { (83 samples) }\end{array}$} & Cow (13) & 11 & 0 & $33.1 \pm 1.9 \quad^{2} \quad 38.7 \pm 2.2$ \\
\hline & Pork (30) & 25 & $\begin{array}{c}3 \\
340.0 \pm 19.0 \quad 160 \pm 9.0 \\
860.0 \pm 48.2\end{array}$ & $34.2 \pm 1.9 \quad 2 \quad 30.0 \pm 1.7$ \\
\hline & Chicken (10) & 10 & 0 & 0 \\
\hline & Cow/Pork (19) & 16 & $831.0 \pm 46.5{ }^{2} \quad 830.0 \pm 46.5$ & $\begin{array}{c}1 \\
25.1 \pm 1.4\end{array}$ \\
\hline & Horse (7) & 5 & $\begin{array}{c}1 \\
256.0 \pm 14.3\end{array}$ & $\begin{array}{c}1 \\
21.9 \pm 1.2\end{array}$ \\
\hline & Horse/Pork (4) & 3 & $\begin{array}{c}1 \\
1015.0 \pm 56.8\end{array}$ & 0 \\
\hline \multirow{4}{*}{$\begin{array}{l}\text { Minced meat } \\
\text { (38 samples) }\end{array}$} & Cow (5) & 5 & 0 & 0 \\
\hline & Pork (15) & 13 & $\begin{array}{c}2 \\
253.0 \pm 14.2 \\
237.0 \pm 13.3\end{array}$ & 0 \\
\hline & Cow/Pork (13) & 11 & $\begin{array}{l}{ }^{2} \\
191.0 \pm 10.7 \\
170.0 \pm 9.5\end{array}$ & 0 \\
\hline & Chicken (5) & 4 & $\begin{array}{ll}1 & \\
& 331.0 \pm 18.5\end{array}$ & 0 \\
\hline
\end{tabular}

${ }^{\mathrm{a}}$ Expressed as $\mathrm{mg} \cdot \mathrm{kg}^{-1}$ of Ascorbic acid \pm expanded measurement uncertainty percentage. 


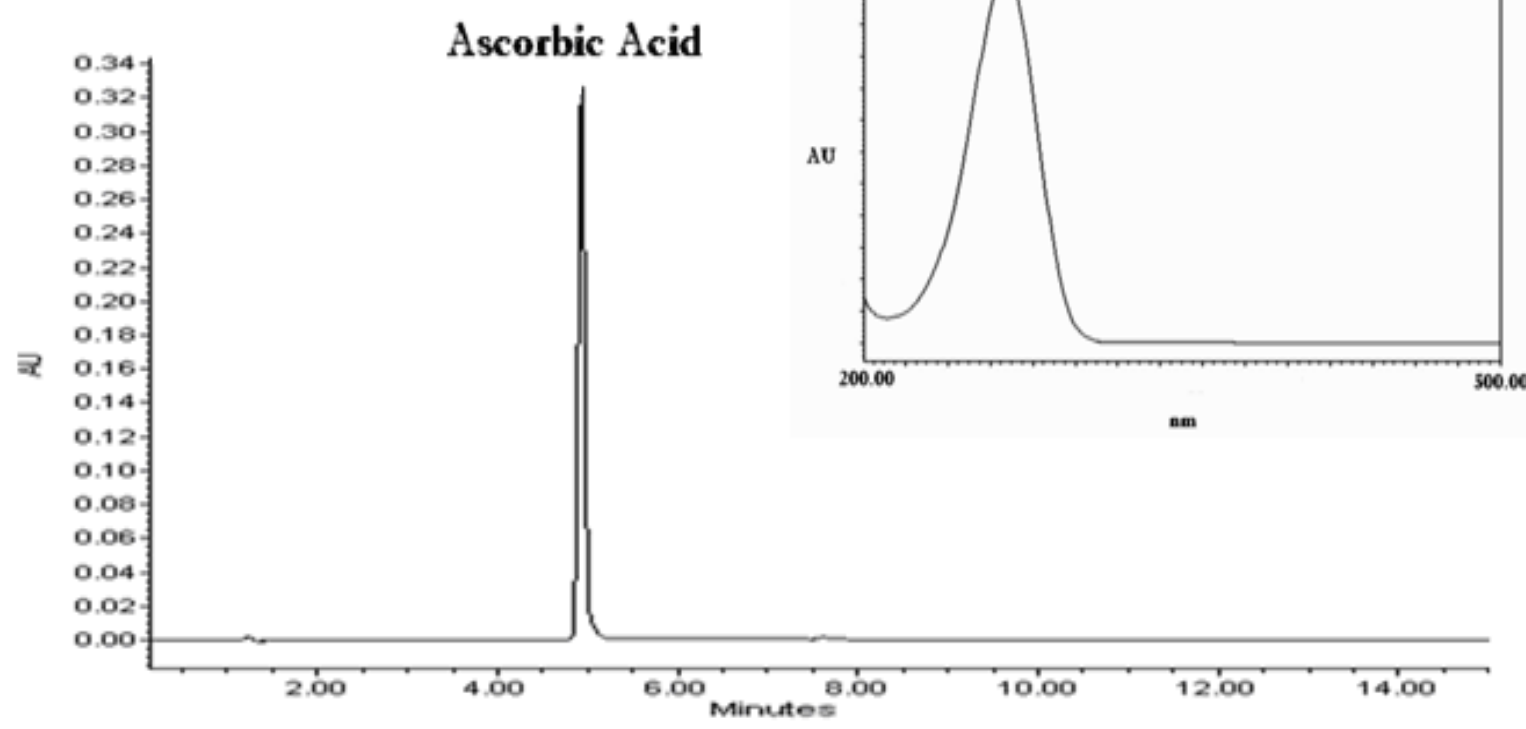

Figure 1. Chromatogram of an ascorbic acid standard solution at a concentration of $50 \mathrm{mg} \mathrm{L}^{-1}$. The related absorbance spectrum is shown in the box 

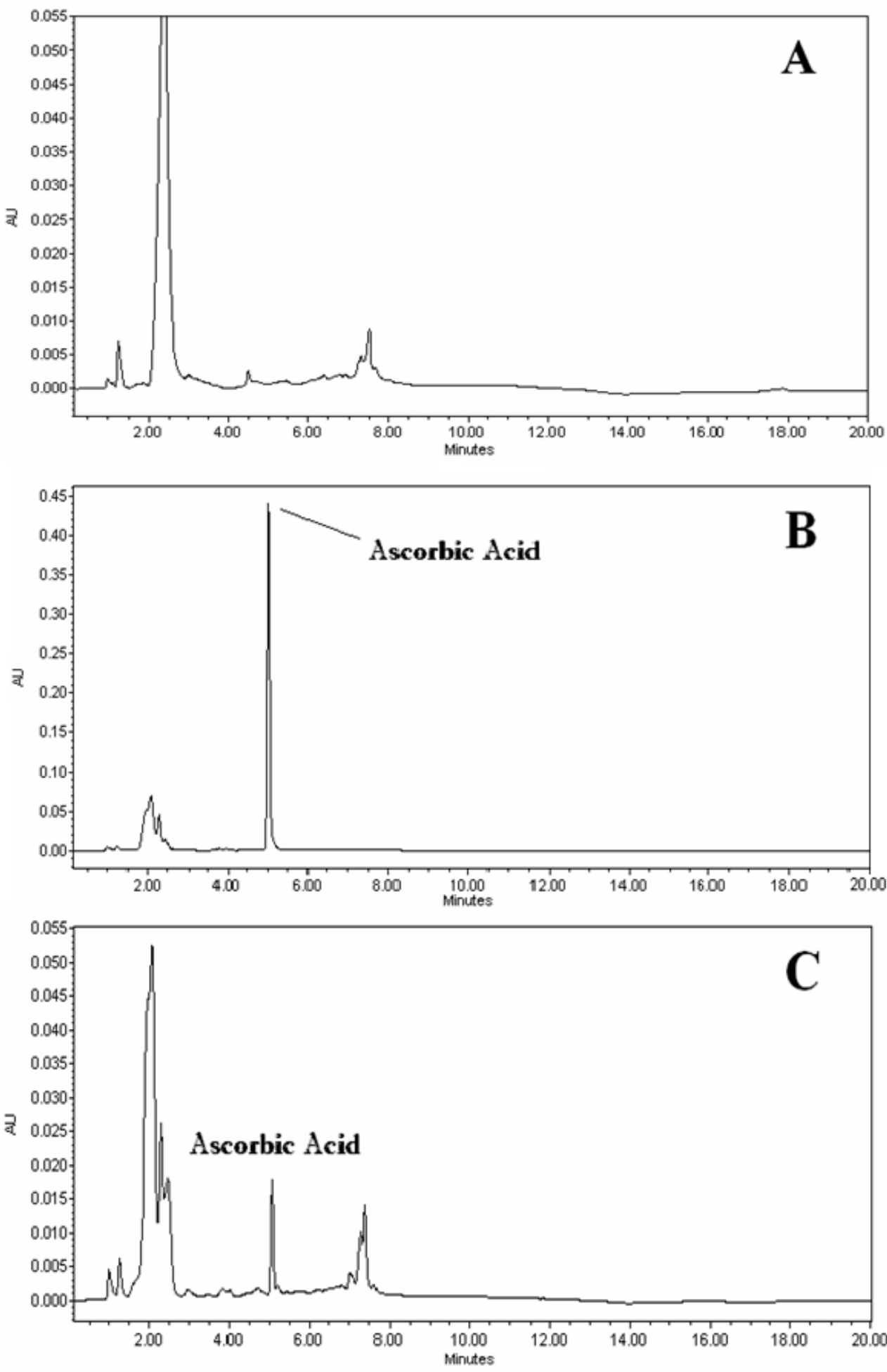

Figure 2. Chromatograms comparison: Blank cow fresh meat sample (A); "Not-compliant" sample: fresh cow/pork sausage with an observed ascorbic acid concentration of $831.0 \mathrm{mg} \mathrm{kg}^{-1}$ (B); "Compliant" sample: cow/pork hamburger with an observed ascorbic acid concentration of $32.9 \mathrm{mg} \mathrm{kg}^{-1}$ (C) 


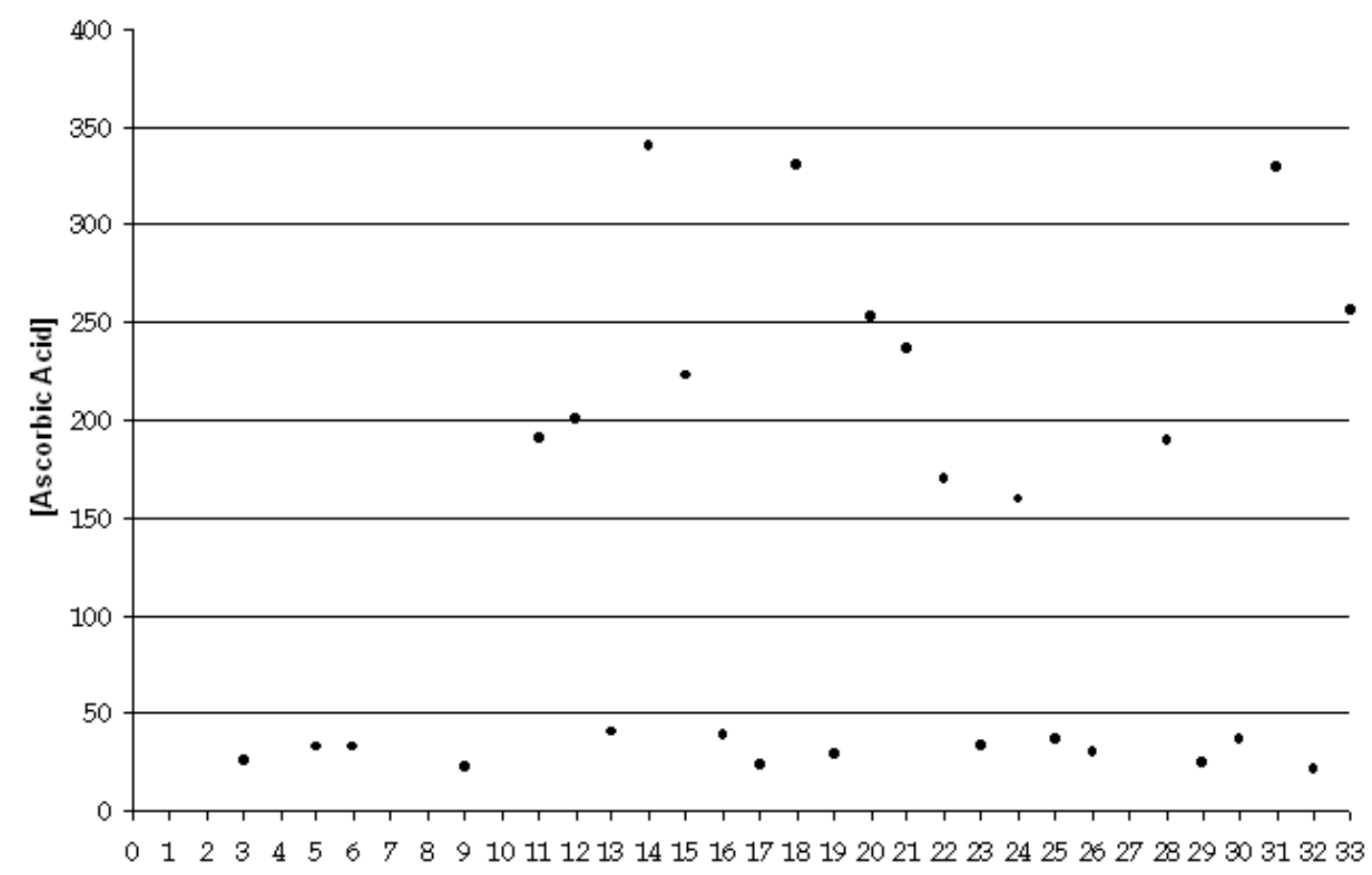

Figure 3. Distribution of ascorbic acid concentrations observed in positive samples. Values indicated as $\mathrm{mg} \mathrm{kg}^{-1}$ of ascorbic acid

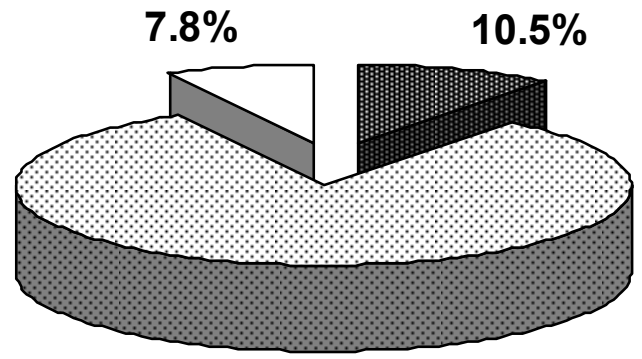

$81.7 \%$
圈 "Not Compliant" samples

은 Negative samples

$\square$ "Compliant" samples

Graphic 1. Subdivision into negative, "Not-compliant" and "Compliant" samples 